\title{
Innovation in Resourcing Geological Materials as Crop Nutrients
}

\author{
David A. C. Manning $\oplus^{1,2}$
}

Received 19 January 2017; accepted 24 May 2017 Published online: 1 June 2017

Mineral resources are fundamental to the growth and development of human society. Extraction of metal ores has risen very slightly as a proportion of all resources, while construction and industrial mineral extraction has grown much more rapidly. This reflects growth in GDP, which is much faster than population growth, in turn reflecting improved standards of living, growth in urban housing/infrastructure and growth in the consumer society. Fertilizer minerals in particular are essential resources for production of the food needed by an increasing global population. Nitrogen fertilizer manufacture requires fossil fuels-especially natural gas (methane) as a source of the hydrogen needed for the HaberBosch process. Phosphate fertilizers are predominantly manufactured using phosphate rock as a source of phosphoric acid, and there is scope to recover phosphorus from contaminated waters. Potassium fertilizers are produced from evaporite deposits, mainly in the global north. It is difficult for poorer countries with deeply leached soils to access and make efficient use of existing conventional products. Globally, while $\mathrm{N}$ and $\mathrm{P}$ fertilizer application replaces the nutrient removed by crops and so is in balance, twice as much $\mathrm{K}$ is being removed from soils as is being replaced. This leads to the need for innovation in developing novel sources of $\mathrm{K}$, especially to support agricultural production in the global south. Rocks containing $\mathrm{K}$ silicate minerals (such as feldspar and nepheline) occur widely as potential sources of $\mathrm{K}$ for use in soils where these minerals weather rapidly. Observations of surface corrosion in feldspars taken from soils after 10 years exposure to soil microbial systems demonstrates rates of dissolution 4 orders of magnitude greater than determined in the laboratory. Innovation in use of these minerals depends on an understanding of the role of microbial processes in silicate mineral decomposition.

KEY WORDS: Population growth, Urban development, Food security, Nitrogen, Phosphorus, Potassium.

\section{KEY DRIVERS FOR MINERAL EXTRACTION}

The purpose of this paper is to reflect, from a geological perspective while drawing on other dis-

\footnotetext{
${ }^{1}$ School of Civil Engineering and Geosciences, Newcastle University, Newcastle upon Tyne NE1 7RU, UK.

${ }^{2}$ To whom correspondence should be addressed; e-mail: david.manning@ncl.ac.uk
}

ciplines, on the future supply of raw materials needed to produce fertilizers that will enable agriculture to feed 9 billion people by 2050, given that these raw materials are mined. Using evidence from a range of published sources to demonstrate increase in future demand due to population growth, coupled with global nutrient balance assessments, the paper focuses (with examples) on innovative developments concerning the supply of potassium (K). This essential plant nutrient is derived currently from 
mined potash, a commodity whose production globally is dominated by a small number of sources that occur principally in the northern hemisphere. While supply meets the needs of the developed world, much of the developing world fails to use adequate amounts of conventional potash, leading to a need for novel alternatives that meet local requirements.

Society's need for mineral raw materials is a defining aspect of human development; mankind has used geological raw materials since the Stone Age. Industrialization has depended on the availability of minerals of many kinds; the industrial revolution in the UK started at locations where coal, and iron ore, could be mined. Awareness of the scale of demand, and how it is increasing, led to consideration of the 'Limits to Growth' (Meadows et al. 1972), which highlighted the finite 'life expectancy' of minerals, as defined by the quantities declared as ore 'reserves.' However, this approach is not valid as it needs to take into account the rules by which reserves are defined (USGS 2011), which mean that estimates of reserves are continually revised as additional quantities of material that can be mined profitably using current technology are progressively defined in accordance with established protocols.

In the context of material flow analysis (MFA), the Global Material Flows Database (Wien Universität 2014) divides extracted materials into four categories: 'metal ores,' 'fossil fuels,' 'industrial and construction minerals' and 'biomass.' The first three are, necessarily, geological raw materials, whereas biomass production depends on the ability of the minerals present in soil to provide nutrients for plant growth. In more detail, a number of studies have carried out MFA for specific commodities to assess the security of their supply as the first step in any supply chain. These studies have addressed metals (e.g., Henckens et al. 2014; Graedel et al. 2015), and although alternative sources and recycling are considered as ways of making better use of limited resources to maintain the stocks that society needs, there appear to be no alternatives other than reducing consumption. Industrial and construction minerals have received much less attention; quantitatively, they are dominated by sand, gravel and aggregates needed for construction, where trade is limited geographically given the cost of transport and the need for local sources for specific markets. Future projections that consider how requirements for industrial and construction minerals will change are lacking. Schaffartzik et al. (2014) report gross metabolic rates in terms of mass of mineral consumed per capita for 171 countries and a wide range of metals and industrial minerals; based on historic trends on a regional basis, they predicted future growth in mineral production, but this was not quantified.

As indicated by Schaffartzik et al. (2014), growth in demand for minerals is linked not just to population growth but to growing demand per capita. This is summarized in Figure 1a, which shows the amounts of mineral extracted, distinguishing metal ores from industrial and construction minerals as defined in the Global Material Flows Database (Wien Universität 2014). Rates of mineral extraction are increasing, but the proportion of extraction of industrial and construction minerals (compared with the total of all extracted raw materials) has risen from 20 to $30 \%$ between 1980 and 2013, whereas the proportion of metal ores has risen from 10 to $12 \%$ (Fig. 1b). This reflects increasing urbanization, with the need for construction materials (especially cement and aggregates) to build cities and the associated infrastructure. It also reflects the way in which industrial and construction minerals are essential raw materials for the production of consumer goods such as plastics, packaging film and paper (where they are used functionally as fillers and coatings). Increasing production of industrial minerals reflects growth in gross domestic product (and growth of the consumer society), which increases at a rate that is much greater than population growth (Fig. 2), reflecting greater prosperity.

Growth in the extraction of mineral raw materials appears to be continuous and relentless, with greatest growth in the least studied field-that of industrial and construction minerals (as defined by Wien Universität 2014). A subset of growth within that category concerns the raw materials mined to produce fertilizers, which are especially important given the need to feed a growing population in the context of reducing availability of arable land, per capita, to raise that population above subsistence farming (so that it can participate in the global economy), and at the same time not compromise the global environment.

\section{MINERAL-DERIVED FERTILIZERS}

Global agriculture depends on three major nutrients, nitrogen, phosphorus and potassium $(\mathrm{N}, \mathrm{P}$ and $\mathrm{K}$ ), all of which are applied as products manu- 

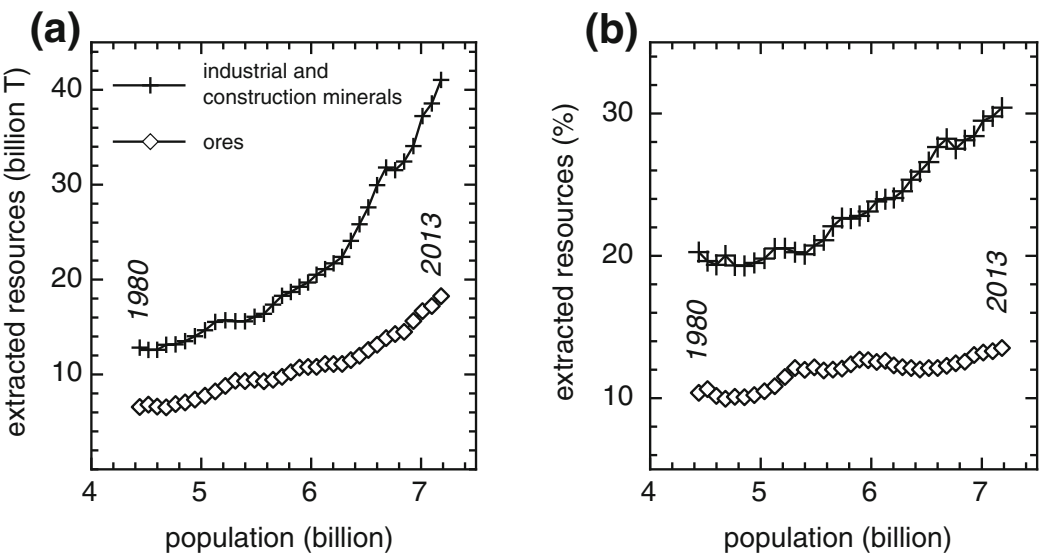

Figure 1. Growth in extraction of mined mineral resources, 1980-2013 (Wien Universität 2014), expressed in (a) absolute terms and (b) as proportion of total resource extraction.

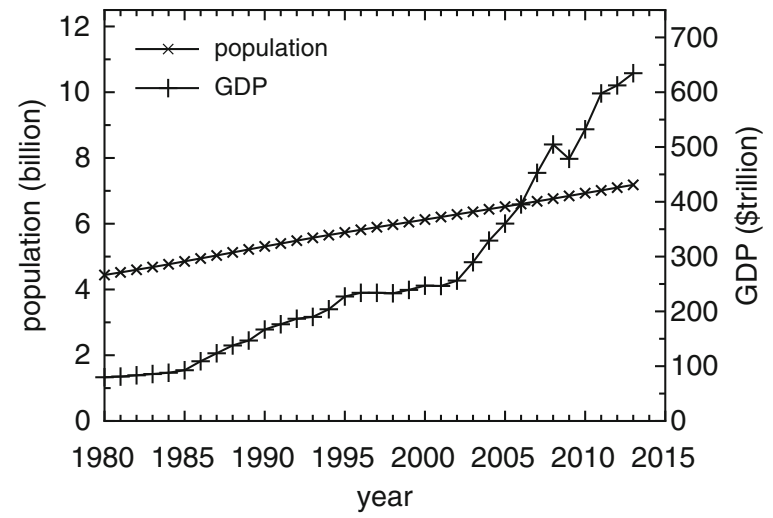

Figure 2. Changes in world population and gross domestic product (GDP) between 1980 and 2013 (World Bank World Development Indicators 2016).

factured from mined materials. Each is considered briefly in turn, as each has very specific characteristics.

\section{Nitrogen}

The world's $\mathrm{N}$ fertilizers are produced by the Haber-Bosch process, which was introduced at the start of the twentieth century. Haber invented a process, commercialized by Bosch (Smil 2001), by which $\mathrm{N}$ from the air is used to produce ammonia, by reaction with hydrogen $(\mathrm{H})$ over a catalyst. The $\mathrm{H}$ needed for this reaction is derived from methane or syngas (carbon monoxide-hydrogen). At present, 140 million tonnes of ammonia are produced annually, almost entirely for fertilizer use

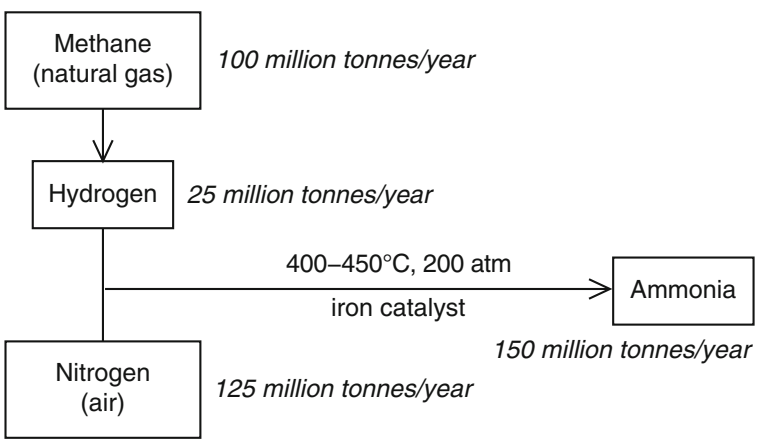

Figure 3. Summary of the Haber-Bosch process, indicating the quantities of raw materials required for current annual production of ammonia.

(Apodaca 2017). If the required $\mathrm{H}$ is wholly sourced from natural gas (Fig. 3), the process would use about $5 \%$ of the world's production of methane as a raw material, in addition to accounting for $1 \%$ of global energy consumption (Lægrid et al. 1999).

The Haber-Bosch process illustrates the potential importance of methane as a raw material as well as a fuel, and the value of the petroleum industry as a source of materials, not just fuels, that are essential for human well being. It is widely stated that the Haber-Bosch process, and the ensuing availability of $\mathrm{N}$ fertilizers, is one of the major factors that enabled the world's population to grow from less than 2 billion at the start of the twentieth century to 7 billion one hundred years later (e.g., Smil 2001). The Haber-Bosch process, and with it our ability to produce $\mathrm{N}$ fertilizers, depends on the existence of a substantial petrochemical industry, 
and to a lesser extent a coal gasification industry, to produce syngas.

Clearly, fossil fuels extracted from the Earth provide essential raw materials needed to support future populations. The move away from carbonbased energy sources is necessary from the point of view of preventing future increases in atmospheric $\mathrm{CO}_{2}$, and the associated effects on climate change. However, the only way methane or syngas can be removed as a raw material in the Haber-Bosch process would be for an alternative source of $\mathrm{H}$ to be developed. The quantities required are enormous, and it is hard to see what the alternatives might be, especially given the likely associated energy requirements.

\section{Phosphorus}

Almost all of the world's $\mathrm{P}$ is derived from the apatite family of minerals (Van Kauwenbergh 2010; Al Rawashdeh and Maxwell 2011), which occur mainly in sedimentary deposits (carbonate fluorapatite; francolite: $\left.\left(\mathrm{Ca}_{5}\left(\mathrm{PO}_{4}, \mathrm{CO}_{3}, \mathrm{OH}\right)_{3}(\mathrm{OH}, \mathrm{F})\right)\right)$ but also in igneous rocks (hydroxyapatite, fluorapatite, chlorapatite: $\left(\mathrm{Ca}_{5} \mathrm{PO}_{4}\right)_{3}(\mathrm{OH}, \mathrm{F}, \mathrm{Cl})$; Manning 2008; e.g., phosagro.com). Once mined, these minerals are treated with concentrated sulfuric acid to produce phosphoric acid $\left(\mathrm{H}_{3} \mathrm{PO}_{4}\right)$ and 'phosphogypsum' $\left(\mathrm{CaSO}_{4} \cdot 2 \mathrm{H}_{2} \mathrm{O}\right)$. Phosphoric acid is then used to produce chemical fertilizers and other chemical products. Phosphate rock can be used directly as a fertilizer, following crushing and grading, and in this form is acceptable for organic food production (Nelson and Jahnke 2007), provided there is negligible risk of contamination from heavy metals or uranium (Jiao et al. 2012). About 220 million tonnes of $\mathrm{P}_{2} \mathrm{O}_{5}$ equivalent are mined globally each year, over $98 \%$ of this from 23 countries (Jasinski 2016a).

The availability of $\mathrm{P}$ as a non-renewable resource has recently been suggested as a cause for concern, through discussion of the concept of 'peak phosphorus' (Cordell et al. 2009; Ulrich and Frossard 2014). Evidence of scarcity was based in part on the published reserves of P (e.g., Jasinski 2016a), which suggested that known reserves would be exhausted in 100 years (Fig. 4). However, following the publication of Cordell et al. (2009), the way in which $P$ reserves are determined and reported was changed, increasing the amounts by a factor of 3 (Fig. 4). 'Peak phosphorus' appears to have been overtaken by events, although it is indeed the case

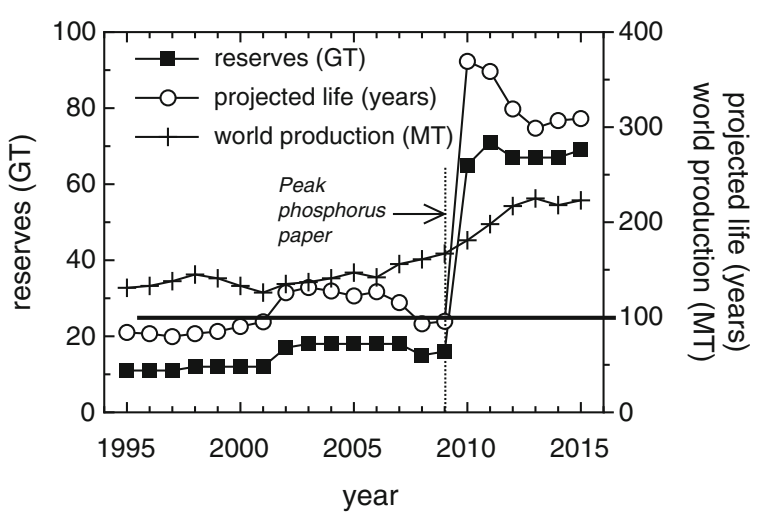

Figure 4. Changes in estimation of 'reserves' and production rates of phosphate rock (expressed as tonnages of $\mathrm{P}_{2} \mathrm{O}_{5}$ equivalent; Jasinski 2016a) and calculated life for reserves (amount divided by production).

that, at the time of writing, Cordell et al. (2009) were addressing a potential problem.

An alternative to mined $\mathrm{P}$ is the use of struvite $\left(\mathrm{MgNH}_{4} \mathrm{PO}_{4} \cdot 6 \mathrm{H}_{2} \mathrm{O}\right)$ recovered from wastewaters (Rahman et al. 2014; Talboys et al. 2016). Although demonstrated to act as an effective slow-release source of $\mathrm{P}$ for plant growth, struvite is not widely used as a fertilizer material. In addition to recovering $\mathrm{P}$ from waste streams, struvite production also removes $\mathrm{N}$, thereby further mitigating the impact of wastewater contamination. To produce struvite, magnesium is required, and its incorporation into this mineral provides an additional valuable plant nutrient.

\section{Potassium}

Potassium (K) differs from $\mathrm{P}$ and $\mathrm{N}$; at present, conventional $\mathrm{K}$ fertilizers are produced predominantly from mined salts (potash; Cocker et al. 2016), especially sylvite $(\mathrm{KCl})$ and carnallite $\left(\mathrm{MgCl}_{2} \cdot \mathrm{KCl} \cdot 6 \mathrm{H}_{2} \mathrm{O}\right)$ or brines, and require much less chemical processing to produce a fertilizer product (Ciceri et al. 2015). About 39 million tonnes of $\mathrm{K}_{2} \mathrm{O}$ equivalent are mined from 12 countries, with a trivial amount produced elsewhere $(50,000 \mathrm{~T}$; Jasinski 2016b). World production is dominated by 10 major companies and mostly comes from North America, Belarus and Russia.

Historically, the $\mathrm{K}$ fertilizer industry has experienced major, technically innovative, changes connected to geopolitical developments (Rittenhouse 1979; Al Rawashdeh and Maxwell 2014; Ciceri et al. 
2015; Al Rawashdeh et al. 2016). Initially produced from wood ash, ashed kelp became important as a source of $\mathrm{K}$ in the early nineteenth century (as well as in the early twentieth century in the USA). However, by the mid-nineteenth century, potash salts were being produced in Germany. German control of mined potash in the early twentieth century led to an urgent need for alternative sources, including investigation of silicate minerals as a source of $\mathrm{K}$ in Norway, North America and the UK (Ciceri et al. 2015). The geopolitical world of potash changed completely with the discovery and development of the Canadian potash deposits, which led to the start of the present global potash market, with commercial production starting in 1962, closely followed by the UK's Boulby potash mine in 1969 (Woods 1979). More recent developments in the UK have led to large-scale plans to mine polyhalite $\left(\mathrm{K}_{2} \mathrm{SO}_{4} \cdot 2 \mathrm{CaSO}_{4} \cdot \mathrm{MgSO}_{4} \cdot 2 \mathrm{H}_{2} \mathrm{O}\right)$ as an additional $\mathrm{K}$ source that also supplies $\mathrm{Ca}, \mathrm{Mg}$ and $\mathrm{S}$ (up to 20 million tonnes per year; Kemp et al. 2016; Sirius Minerals 2016).

\section{FUNDAMENTAL DEMAND FOR FERTILIZER MINERALS: MORE MOUTHS TO FEED}

The availability of food needed to support an increasing global population depends on a range of factors (Godfray et al. 2010), of which fertilizer supply is one (Gregory and George 2011; Jones et al. 2013). A key function of soil is to deliver the major and minor nutrients that are needed by all plants, irrespective of whether or not they are specially bred or arise from genetic modification. Given that the land area for food production per capita has decreased from 0.415 to 0.214 ha between 1961 and 2007 (Gregory and George 2011) and that average yields of cereal need to rise from $3.23 \mathrm{t} \mathrm{ha}^{-1}$ in 2005/ 07 to $4.34 \mathrm{t} \mathrm{ha}^{-1}$ in 2030 (Smith et al. 2010), it is necessary to ensure that soils can deliver the nutrients that plants require. Improvements in nutrient use efficiency are essential for future food production and include improvements to fertilizer design as well as plant breeding and/or genetic modification (Gregory and George 2010).

To assess the need for fertilizers on a global scale, the amount of nutrient removed through harvesting needs to be known. Soils require fertilizers to compensate for those removed when crops are taken away (Jones et al. 2013). The removal of nutrients with crops is described as 'offtake,' and farmers are advised to maintain the soil nutrient 'bank' by replacing offtake with 'inputs' of applied fertilizer (Khan et al. 2013).

Studies of nutrient balance using MFA provide an estimate of fertilizer demand at a range of scales, from single farms to countries and geopolitical regions (Sheldrick et al. 2002). Although a number of publications report nutrient balances for $\mathrm{P}$ and/or $\mathrm{N}$ (e.g., Vitousek et al. 2009; Bateman et al. 2011; MacDonald et al. 2011; Dungait et al. 2012), very few address $\mathrm{K}$ and fewer provide an internally consistent and directly comparable set of data. Consideration of global nutrient balances in the second half of the twentieth century (Sheldrick et al. 2002) indicates that $\mathrm{K}$ is the nutrient that is being removed most significantly from soils. Overall, world production of potash needs to double to compensate for the deficit calculated by Sheldrick et al. (2002). In other words, mined production of $\mathrm{K}$ needs to increase to compensate for the dispersed 'mining' of $\mathrm{K}$ from soils through global crop production. The deficit in $\mathrm{K}$ is greatest for Africa (Fig. 5; Sheldrick and Lingard 2004), where $\mathrm{N}$ is in balance (inputs match offtake) and $\mathrm{P}$ has been applied in excess of outputs, with apparently excessive use of $P$ fertilizers (Fig. 5b), whereas more than twice as much $\mathrm{K}$ is removed as offtake than is added as fertilizer and crop residues combined, illustrating the 'potash gap' (Fig. 5c). These basic observations suggest that if soil nutrient status is to be maintained through addition of fertilizers, $\mathrm{N}$ and $\mathrm{P}$ are being managed satisfactorily, but $\mathrm{K}$ inputs need to increase significantly. Additionally, according to FAO (2016) figures, Africa, with $16 \%$ of the world's population, uses $1.6 \%$ of the world's potash, and its population is expected to double between 2015 and 2050, when it will exceed 2 billion (Manning 2015). In these circumstances, conventional sources of $\mathrm{K}$ are apparently not being used, and so alternative sources of $\mathrm{K}$ increasingly need to be investigated.

\section{NOVEL SOURCES OF K AS A CROP NUTRIENT}

The above discussion shows that agricultural management on a global scale leads to an overall balance for $\mathrm{N}$ and $\mathrm{P}$; there appears to be no immediate concern that might justify a search for novel fertilizer minerals as sources of these nutrients. However, the dependency of the existing $\mathrm{N}$ fertilizer 

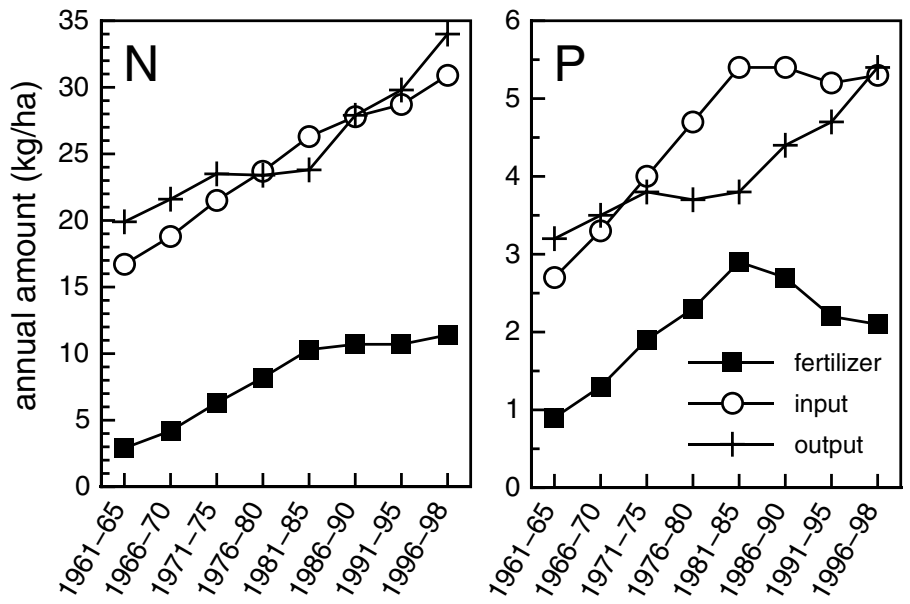

years

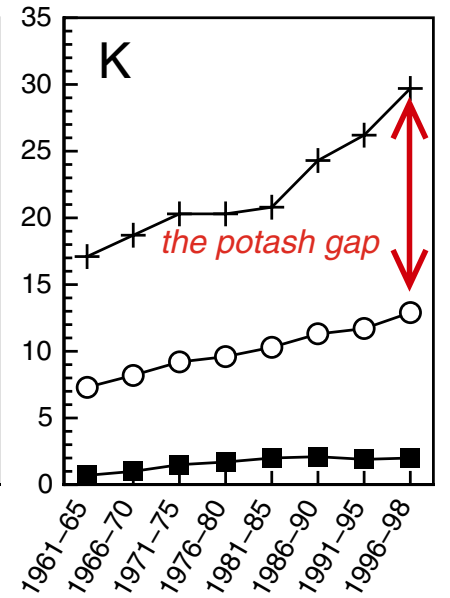

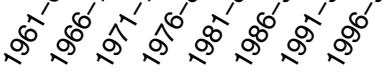

Figure 5. Nutrient balances for N, P and K for Africa, using data from Sheldrick and Lingard (2004).

industry on fossil fuels is a concern given the need to decarbonize the energy economy; $\mathrm{N}$ fertilizer production depends on fossil fuels as raw materials (methane, or syngas produced from methane through reforming or from coal gasification). The possibility of extracting $\mathrm{P}$ from wastewaters as struvite (or in other forms, such as sewage sludge) provides a way of reducing dependency on mined phosphate rock, but it is an engineering, not a geological, problem.

Potassium differs from $\mathrm{N}$ and $\mathrm{P}$. As explained clearly by Cocker et al. (2016), the global demand for $\mathrm{K}$ is very skewed: 'Obtaining sufficient amounts of potash is a global trade issue, usually involving rail and ocean transportation over vast distances. Because potash is a bulk commodity where its end cost is governed greatly by the cost of transportation, the proximity of a nation to potash deposits and the availability of low-cost transportation determine the price that a nation will pay for fertilizer.' In these circumstances, the prosperous global north evidently can afford to compensate for crop offtake by application of potash derived from a global market that is dominated by two northern hemisphere source regions, Canada and Belarus-Russia (Sheldrick et al. 2002). In contrast, the global south has few commercial potash deposits and, given the need for transport over long distances, has limited access to the existing conventional market.

Although conventional potash deposits in evaporite basins, suitable for mining economically using current technologies (Cocker et al. 2016), are not widely distributed globally, $\mathrm{K}$ is the seventh most abundant element in the Earth's crust, occurring widely in silicate minerals. Potassium feldspars $\left(\mathrm{KAlSi}_{3} \mathrm{O}_{8}\right)$ contain up to a theoretical maximum of almost $17 \% \mathrm{~K}_{2} \mathrm{O}$, and micas (e.g., biotite $\mathrm{K}(\mathrm{Mg}, \mathrm{Fe})_{3} \mathrm{AlSi}_{3} \mathrm{O}_{10}(\mathrm{OH})_{2}$ and muscovite

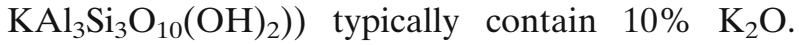
Less common $\mathrm{K}$-bearing silicate minerals include the feldspathoids nepheline $\left((\mathrm{Na}, \mathrm{K}) \mathrm{AlSiO}_{4} ; 4-12 \%\right.$ $\mathrm{K}_{2} \mathrm{O}$; Deer et al. 2004) and leucite $\left(\mathrm{KAlSi}_{2} \mathrm{O}_{6} ; 21 \%\right.$ $\mathrm{K}_{2} \mathrm{O}$ if pure $)$, and the mica glauconite $((\mathrm{K}, \mathrm{Na})$ $\left(\mathrm{Fe}^{3+}, \mathrm{Al}, \mathrm{Mg}\right)_{2}(\mathrm{Si}, \mathrm{Al})_{4} \mathrm{O}_{10}(\mathrm{OH})_{2}$; typically $6 \% \mathrm{~K}_{2} \mathrm{O}$; Deer et al. 2013), which occurs in greensand, a historical source of $\mathrm{K}$.

A number of studies have investigated the possible use of silicate minerals as sources of $\mathrm{K}$ for crop growth, in circumstances where conventional potash is either inaccessible for geographic or economic reasons, or when salts are less suitable because of rapid removal from soils through leaching (Leonardos et al. 1987). Early work focused on Norwegian nepheline syenites, at a time after World War 1 when Germany controlled potash markets (Goldschmidt 1922; Goldschmidt and Johnsen 1922). More recently, Bakken et al. (1997, 2000) demonstrate the potential of nepheline-bearing rocks (nepheline syenite) to provide $\mathrm{K}$ for plant growth. Other work on silicate rocks, such as granite, has been less successful (Harley and Gilkes 2000; Manning 2010). However, exploitation of silicate rocks, with low $\mathrm{K}_{2} \mathrm{O}$ contents compared with evaporate-derived potash, involves movement of greater 
quantities of material if application rates are based on grade, and higher transport costs. Such materials can be produced from surface mines with technologies and costs associated with the production of construction aggregates, where 'quarry fines' are a normal by-product of crushing (typically $25-30 \%$ of crusher feed). Quarry fines represent the lowest cost source of such materials, to which value (and cost) can be added by milling or other processing.

Brazil provides an example of need driving innovation. Brazil imports $90 \%$ of its potash requirements and cultivates deeply leached soils that require repeated application to compensate for $\mathrm{K}$ removed through leaching. In these circumstances, Brazil has pioneered investigations of novel sources of $\mathrm{K}$ from silicate rocks. Recent work has focused on 'verdete,' a glauconite and feldspar-bearing metamorphic rock that contains $5-15 \% \quad \mathrm{~K}_{2} \mathrm{O}$ (www.verdefertilizantes.com.br; Santos et al. 2015), and syenite (12-14\% $\mathrm{K}_{2} \mathrm{O}$; Pessoa et al. 2015; Ciceri et al. 2017). Laboratory studies show that $\mathrm{K}$ release from silicates is very slow (verdete: Silva et al. 2012; syenite: Ciceri et al. 2017), although innovative approaches to measuring dissolution (Ciceri and Allanore 2015) have shown rates 10-100 times greater than achieved in batch leaching experiments. A number of approaches have been taken to compensate for slow reaction rates by milling, or by liberating $\mathrm{K}$ from the mined silicate through calcining with fluxes or acid leaching (verdete: Santos et al. 2015; nepheline syenite: Jena et al. 2014; Pessoa et al. 2015; feldspar: Wang et al. 2014). These add to manufacturing processes the cost of reagent and energy inputs.

When considering the use of silicate minerals (and their host rocks) as sources of plant nutrient, it is not the absolute content (i.e., the grade) of the nutrient of interest that is important. Instead, it is the rate at which the mineral dissolves that is important, because it reflects the availability of the nutrient to plants. Conventionally, mineral dissolution rate is determined in laboratory experiments, which yield higher rate values than those determined from field observations (such as through determining solute characteristics of a catchment; White and Brantley 2003). Mineral dissolution rates vary greatly from one mineral to another (Palandri and Kharaka 2004). For example, nepheline (with a maximum of $8 \% \mathrm{~K}_{2} \mathrm{O}$, and typically $2 \%$ or less) dissolves 20 million times more quickly than $\mathrm{K}$ feldspar, explaining why the plant growth experiments by Bakken et al. $(1997,2000)$ were successful, and justifying the use of nepheline-bearing rocks as a source of $\mathrm{K}$, even if their $\mathrm{K}$ contents are lower than other rock types. Nepheline is a much more effective 'slow-release' fertilizer mineral than potassium feldspar.

Pretreatment processes set out to produce a material with high availability of $\mathrm{K}$ that can be measured through chemical extraction procedures in the laboratory, a step that is required for selection of raw materials and for product quality control. The behavior of silicate minerals in soils differs from that in typical laboratory leaching tests, as it is affected by biological processes, reflecting the subsurface ecosystem that exists in the root zone. It is evident from studies of deeply leached tropical soils that silicate minerals weather rapidly (Leonardos et al.1987); the mineral assemblage in such soils that is at equilibrium, chemically, with the conditions of weathering is dominated by oxy-hydroxide minerals. In such soils, the application of a silicate mineral that is unstable thermodynamically under Earth surface conditions is expected to provide a source of $\mathrm{K}$ (and other nutrients, including silica). However, careful experimental design is required to demonstrate that the $\mathrm{K}$ required for plant growth has indeed come from the silicate mineral that has been applied. For example, Mohammed et al. (2014) considered the mineralogical composition specifically of the soil used in experimental trials, showing that a statistically significant plant response to application of feldspar is observed for artificial and natural sandy soils that lacked feldspar. In contrast, studies that used soil that already included the minerals applied as treatments (i.e., the added mineral is weathering at the same rate as those already in the soil) showed no growth response (e.g., Ramezanian et al. 2013). Confirmation of the ability of potassium feldspar, in the form of syenite and as the only possible source of $\mathrm{K}$ for plant growth, was confirmed in careful experiments using an artificial soil based on high-purity quartz (Manning et al. 2017).

Finding new sources of $\mathrm{K}$ from silicate minerals and rocks is an old idea (Ciceri et al. 2015) and is not a major concern for the global north given the ready availability of potash. However, to satisfy global demand for $\mathrm{K}$, as indicated by crop offtake, conventional potash production would need to double. In the global south, the use of conventional potash involves high transport costs, and the associated infrastructure is often poor. In these circumstances, local needs justify consideration of local silicate rocks as a source of $\mathrm{K}$ (Leonardos et al. 1987). 
The key to understanding the ability of silicate rocks to provide $\mathrm{K}$ is their stability in soils. If a soil already contains a specific silicate mineral, such as $\mathrm{K}$-feldspar, the addition of more $\mathrm{K}$-feldspar is unlikely to increase the amount of $\mathrm{K}$ in the soil solution, as this will be controlled by the weathering reaction that controls the dissolution of the feldspar. If feldspar is added to a soil in which the mineral is absent because it has been removed through natural weathering processes, the added feldspar will also weather, releasing K. Such soils include those in which oxy-hydroxide minerals occur together with kaolinite (a clay product of feldspar weathering), as is typical for deeply leached tropical soils (Leonardos et al. 1987).

The ability of silicate minerals to act as a source of $\mathrm{K}$ in temperate soils is affected by the difference in weathering processes, compared with those in tropical soils. Temperate soils are dominated by products of mechanical weathering of preexisting rocks by processes such as glaciation and contain a range of silicate minerals derived, often without substantial chemical weathering, from parent rocks. Nevertheless, silicate mineral weathering does take place; the instability of silicate minerals in temperate soils is evident from their ability to produce a crop, for example, of wheat. Grasses of this type contain up to $1 \% \mathrm{SiO}_{2}$, and this can only be derived from silicate minerals (excluding quartz, which is stable in temperate soil systems). Silicate minerals, such as wollastonite, are added to soils in which they are lacking for some crops to provide a source of silica (e.g., sugar cane; Savant et al. 1999).

Evidence from all soils shows that silicate minerals, including feldspars, dissolve more quickly than as indicated in laboratory experiments. Figure 6 shows the surface of a feldspar grain that was collected 10 years after being placed in soil in the UK following excavation from depths $>400 \mathrm{~m}$ as drill cuttings from a borehole into a buried granite (Manning et al. 2007). Characteristically, such feldspars show evidence of the development of a microbial community on the grain surface and evidence of corrosion. In the example shown in Figure 6, the scale of corrosion in grains following 10 years exposure to soil conditions suggests cavities with a length dimension of the order of $100 \mu \mathrm{m}$, which for a $1 \mathrm{~mm}$ diameter grain would give a maximum life of the order of 100 years. Using dissolution rates determined experimentally, the life of a $1 \mathrm{~mm}$ diameter feldspar grain is estimated to be 921,000 years (Drever 1997). The corrosion ob-

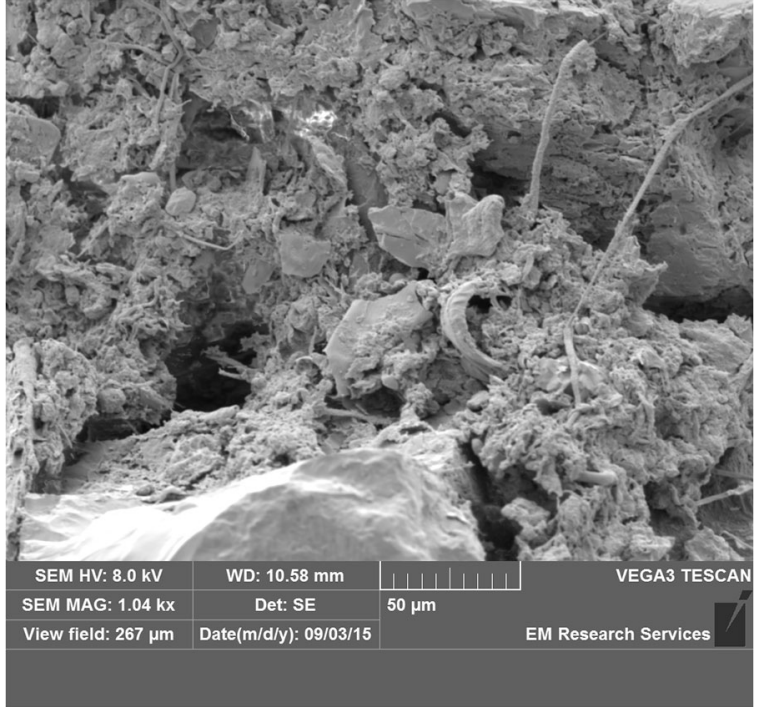

Figure 6. Corroded surface of potassium feldspar after 10 years exposure to soil conditions.

served in grains of feldspar from soil indicates a rate of dissolution $10^{4}$ times greater than predicted from laboratory experiments and 100 times greater than those reported by Ciceri and Allanore (2015). The close association of soil microbial communities with corrosion of feldspar suggests that these play a major role in accelerating its dissolution.

Conventional potash contains water-soluble $\mathrm{K}$ and is the ideal source for a wide range of soils, especially in temperate regions. Alternative sources of $\mathrm{K}$ are required in circumstances where conventional potash is inaccessible-because of price or logistical reasons including transport costs. Potassium silicate minerals have the potential to provide $\mathrm{K}$ for crop growth, but their performance depends on their dissolution rates, the soil environment and the soil microbial community. Thus, their evaluation and development as commodities requires plant growth experiments in specific soils, and necessarily their trade is local.

\section{CONCLUSIONS}

Innovation in the use of geological materials as crop nutrients depends on the nutrient concerned. For nitrogen, the innovation required is to move away from the use of fossil fuels as a source of hydrogen needed to produce ammonia using the Haber-Bosch process. This is a major challenge, given the quantities of raw material that are re- 
quired, and indeed may be undesirable given the need for raw materials derived from fossil fuels for other purposes. For phosphorus, the recovery of $\mathrm{P}$ from wastewaters, for example as struvite, has potential; the innovation required here lies in the engineering design of the process so that it can be used economically in water treatment works, bearing in mind the long life time of these as substantial capital investments.

For potassium, the innovation lies in developing new mineral sources of $\mathrm{K}$ to complement and supplement the current production of sylvite and other evaporite minerals. The need demonstrated from global crop offtake studies is sufficient to justify additional sources of $\mathrm{K}$, as the amounts presently mined represent about half of what is needed to replace $\mathrm{K}$ removed from soils by cropping, even taking into account use of crop residues (such as stalks and leaves, which may or may not be composted before returning to the land). There is a particular need for novel sources of $\mathrm{K}$ for use in the global south, where fertilizers need to be selected specifically for soil types that differ from those in the global north. New mineralogical sources of $\mathrm{K}$ include both salts and silicates. Polyhalite is currently of interest, with major deposits in the UK that are planned to produce significant inputs to the market that dwarf existing production of this mineral. Glauconite-bearing verdete, and syenite, are receiving particular attention in Brazil.

Silicate minerals have a particular role to play as fertilizers in oxisols, which typically develop through the weathering of silicate rocks in deeply leached tropical soils. In these conditions, the instability of potassium feldspars (and nepheline) is demonstrated by the natural development of soil dominated by kaolinite and oxides produced from the weathering of primary silicate minerals that formed part of the parent rock. The extent to which corrosion takes place, even in temperate soils, indicates that weathering of potassium silicates, mediated by soil microbial communities, takes place sufficiently quickly to provide nutrients to growing plants.

\section{ACKNOWLEDGMENTS}

The ideas expressed in this paper have been generated during my employment at Newcastle and Manchester Universities, whose support is acknowledged. Industry support has informed the work, from my fellow shareholders and co-directors in Mineral Solutions Ltd, which developed MSL-K from hard-rock quarry fines as an alternative to conventional potash aimed at the organic farming sector and from previous research funding provided by Terrativa Minerais SA into the use of syenite. I acknowledge support from the Rochagem movement, which has enabled me to participate in that community in Brazil. I thank the three anonymous reviewers who have helped me to improve the paper; however, I alone accept responsibility for its content.

\section{OPEN ACCESS}

This article is distributed under the terms of the Creative Commons Attribution 4.0 International License (http://creativecommons.org/licenses/by/4.0/), which permits unrestricted use, distribution, and re production in any medium, provided you give appropriate credit to the original author(s) and the source, provide a link to the Creative Commons license, and indicate if changes were made.

\section{REFERENCES}

Al Rawashdeh, R., \& Maxwell, P. (2011). The evolution and prospects of the phosphate industry. Mineral Economics, 24, $15-27$.

Al Rawashdeh, R., \& Maxwell, P. (2014). Analysing the world potash industry. Resources Policy, 41, 143-151.

Al Rawashdeh, R., Xavier-Oliveira, E., \& Maxwell, P. (2016). The potash market and its future prospects. Resources Policy, 47, 154-163.

Apodaca, L. E. (2017). Nitrogen (fixed)_ammonia. United States Geological Survey Minerals Commodity Summary. https:// minerals.usgs.gov/minerals/pubs/commodity/nitrogen/mcs-2017nitro.pdf. Accessed March 10, 2017.

Bakken, A. K., Gautneb, H., \& Myhr, K. (1997). The potential of crushed rocks and mine tailings as slow-releasing $\mathrm{K}$ fertilizers assessed by intensive cropping with Italian ryegrass in different soil types. Nutrient Cycling in Agroecosystems, 47, 4148.

Bakken, A. K., Gautneb, H., Sveistrup, T., \& Myhr, K. (2000). Crushed rocks and mine tailings applied as $\mathrm{K}$ fertilizers on grassland. Nutrient Cycling in Agroecosystems, 56, 53-57.

Bateman, A., van der Horst, H., Boardman, D., Kansal, A., \& Carlliel-Marquet, C. (2011). Closing the phosphorus loop in England: The spatio-temporal balance of phosphorus capture from manure versus crop demand for fertiliser. Resources, Conservation and Recycling, 55, 1146-1153.

Ciceri, D., \& Allanore, A. (2015). Microfluidic leaching of soil minerals: Release of $\mathrm{K}^{+}$from K feldspar. PLoS ONE. doi:10. 1371/journal.pone.0139979. 
Ciceri, D., de Oliveira, M., Stokes, R. M., Skorina, T., \& Allanore, A. (2017). Characterization of potassium agrominerals: Correlations between petrographic features, comminution and leaching of ultrapotassic syenites. Minerals Engineering, 102, 42-57.

Ciceri, D., Manning, D. A. C., \& Allanore, A. (2015). Historical and technical developments of potassium resources. Science of the Total Environment, 502, 590-601.

Cocker, M. D., Orris, G. J., \& Wynn, J. (2016). U.S. Geological Survey assessment of global potash production and resources-A significant advancement for global development and a sustainable future. In G. R. Wessel \& J. K. Greenberg (Eds.), Geoscience for the public good and global development: Toward a sustainable future: Geological Society of America Special Paper (Vol. 520, pp. 89-98).

Cordell, D., Drangerta, J.-O., \& White, S. (2009). The story of phosphorus: Global food security and food for thought. Global Environmental Change, 19, 292-305.

Da Silva, A. A. S., Medeiros, M. E., Sampaio, J. A., \& Garrido, F. M. S. (2012). Characterization of verdete from Cedro do Abaeté to the development of a potassium controlled release material (in Portuguese) (Vol. 5, pp. 42-51). Óbidos: Holos.

Deer, W. A., Howie, R. A., Wise, W. S., \& Zussman, J. (2004). Rock forming minerals volume 4B. Framework silicates: Silica minerals, feldspathoids and the zeolites. London: Geological Society.

Deer, W. A., Howie, R. A., \& Zussman, J. (2013). Introduction to the rock forming minerals. London: Mineralogical Society.

Drever, J. I. (1997). The geochemistry of natural waters, third edition: Surface and groundwater environments (p. 436). Englewood Cliffs, N.J.: Prentice-Hall.

Dungait, J. A. J., Cardenas, L. M., Blackwell, M. S. A., Wu, L., Withers, P. J. A., Chadwick, D. R., et al. (2012). Advances in the understanding of nutrient dynamics and management in UK agriculture. Science of the Total Environment, 434, 39-50.

FAO. (2016). Current world fertilizer trends and outlook to 2019. Food and Agriculture Organization (FAO) of the United Nations. http://www.fao.org/documents/card/en/c/7d56821a49ed-4e96-9420-d381fc33da22/. Accessed May 17, 2017.

Godfray, H. C. J., Beddington, J. R., Crute, I. R., Haddad, L., Lawrence, D., Muir, J. F., et al. (2010). Food security: The challenge of feeding 9 billion people. Science, 327, 812-818.

Goldschmidt, V. M. (1922). Oversikgtskart over utbredelsen av de forskjellige kalimineraler I norsk fjeldgrund. Norsk Landmansblad, 41, 268-269.

Goldschmidt, V. M., \& Johnsen, E. (1922). Glimmermineralernes betydning som kalikilde for planterne. Norges Geologiske Unders $\varnothing$ kelse Bulletin, 108, Trondheim, 89 pp.

Graedel, T. E., Harper, E. M., Nassar, N. T., \& Reck, B. K. (2015). On the materials basis of modern society. Proceedings of the National Academy of Sciences, 112, 6295-6300.

Gregory, P. J., \& George, T. S. (2011). Feeding nine billion: The challenge to sustainable crop production. Journal of Experimental Botany, 62, 5233-5239.

Harley, A. D., \& Gilkes, R. J. (2000). Factors influencing the release of plant nutrients from silicate rock powders: A geochemical overview. Nutrient Cycling in Agroecosystems, 56, 11-36.

Henckens, M. L. C. M., Driessen, P. P. J., \& Worrell, E. (2014). Metal scarcity and sustainability, analyzing the necessity to reduce the extraction of scarce metals. Resources, Conservation and Recycling, 93, 1-8.

Jasinski, S. M. (2016a). Phosphate rock. United States Geological Survey Minerals Yearbook. http://minerals.usgs.gov/minerals/ pubs/commodity/phosphate_rock. Accessed January 10, 2017.

Jasinski, S. M. (2016b). Potash. United States Geological Survey Minerals Yearbook. http://minerals.usgs.gov/minerals/pubs/ commodity/potash. Accessed 10 January 2017.
Jena, S. K., Dhawan, N., Rao, D. S., Misra, P. K., Mishra, B. K., \& Das, B. (2014). Studies on extraction of potassium values from nepheline syenite. International Journal of Mineral Processing, 133, 13-22.

Jiao, W., Chen, W., Chang, A. C., \& Page, A. L. (2012). Environmental risks of trace elements associated with long-term phosphate fertilizers applications: A review. Environmental Pollution, 168, 44-53.

Jones, D. L., Cross, P., Withers, P. J. A., DeLuca, T. H., Robinson, D. A., Quilliam, R. S., et al. (2013). Nutrient stripping: The global disparity between food security and soil nutrient stocks. Journal of Applied Ecology, 50, 851-862.

Kemp, S. J., Smith, F. W., Wagner, D., Mounteney, I., Bell, C. P., Milbe, C. J., et al. (2016). An improved approach to characterize potash-bearing evaporite deposits, evidenced in North Yorkshire, United Kingdom. Economic Geology, 111, 719-742.

Khan, S. A., Mulvaney, R. L., \& Ellsworth, T. R. (2013). The potassium paradox: Implications for soil fertility, crop production and human health. Renewable Agriculture and Food Systems, 29, 3-27.

Lægrid, M., Bøckman, O. C., \& Kaarstad, O. (1999). Agriculture, fertilizers and the environment. Wallingford: CABI Publishing.

Leonardos, O. H., Fyfe, W. S., \& Kronberg, B. I. (1987). The use of ground rocks in laterite systems: An improvement to the use of conventional soluble fertilizers? Chemical Geology, 60, 361-370.

MacDonald, G. K., Bennett, E. M., Potter, P. A., \& Ramankutty, N. (2011). Agronomic phosphorus imbalances across the world's croplands. Proceedings of the National Academy of Sciences, 108, 3086-3091.

Manning, D. A. C. (2008). Phosphate minerals, environmental pollution and sustainable agriculture. Elements, 4, 105-108.

Manning, D. A. C. (2010). Mineral sources of potassium for plant nutrition: A review. Agronomy for Sustainable Development, 30, 281-294.

Manning, D. A. C. (2015). How minerals will feed the world in 2050. Proceedings of the Geologists' Association, 126, 14-17.

Manning, D. A. C., Baptista, J., Sanchez Limon, M., \& Brandt, K. (2017). Testing the ability of plants to access potassium in framework silicate minerals. Science of the Total Environment, 574C, 476-481.

Manning, D. A. C., Younger, P. L., Smith, F. W., Jones, J. M., Dufton, D. J., \& Diskin, S. (2007). A deep geothermal well at Eastgate, Weardale, UK: A novel exploration concept for low-enthalpy resources. Journal of the Geological Society of London, 164, 371-382.

Meadows, D. H., Meadows, D. L., Randers, J., \& Behrens, W. W., III. (1972). The limits to growth: A report for the Club of Rome's project on the predicament of mankind. New York: Universe Books.

Mohammed, S. O., Brandt, K., Gray, N. D., White, M. L., \& Manning, D. A. C. (2014). Comparison of silicate minerals as sources of $\mathrm{K}$ for plant nutrition in sandy soil. European Journal of Soil Science, 65, 653-662.

Nelson, N. O., \& Jahnke, R. R. (2007). Phosphorus sources and management in organic production systems. HortTechnology, 17, 442-454.

Palandri, J. L., \& Kharaka, Y. K. (2004). A compilation of rate parameters of water-mineral interaction kinetics for application to geochemical modeling. U.S. Geological Survey Open File Report 2004-1068, Menlo Park, USA.

Pessoa, R. S., Silva, C. A., Moretti, B. S., Furtini Neto, A. E., Inda, A. V., \& Curi, N. (2015). Solubilization of potassium from alternative rocks by humic and citric acids and coffee husk. Ciência e Agrotecnologia, Lavras, 39, 553-564.

Rahman, M. M., Salleh, M. A. M., Rashid, U., Ahsan, A., Hossain, M. M., \& Ra, C. S. (2014). Production of slow release 
crystal fertilizer from wastewaters through struvite crystallization-A review. Arabian Journal of Chemistry, 7, 139155.

Ramezanian, A., Dahlin, A. S., Campbell, C. D., Hillier, S., Mannerstedt-Fogelfors, B., \& Öborn, I. (2013). Addition of a volcanic rockdust to soils has no observable effects on plant yield and nutrient status or on soil microbial activity. Plant and Soil, 367, 419-436.

Rittenhouse, P. A. (1979). Potash and politics. Economic Geology, 74, 353-357.

Santos, W. O., Mattiello, E. M., da Costa, L. M., Abrahão, W. A. P., de Novais, R. F., \& Cantarutti, R. B. (2015). Thermal and chemical solubilization of verdete for use as potassium fertilizer. International Journal of Mineral Processing, 140, 72-78.

Savant, N. K., Korndörfer, G. H., Datnoff, L. E., \& Snyder, G. H. (1999). Silicon nutrition and sugarcane production: A review. Journal of Plant Nutrition, 22, 1853-1903.

Schaffartzik, A., Mayer, A., Gingrich, S., Eisenmenger, N., Loy, C., \& Krausmann, F. (2014). The global metabolic transition: Regional patterns and trends of global material flows, 19502010. Global Environmental Change, 26, 87-97.

Sheldrick, W. F., \& Lingard, J. (2004). The use of nutrient audits to determine nutrient balances in Africa. Food Policy, 29, 61-98.

Sheldrick, W. F., Syers, J. K., \& Lingard, J. (2002). A conceptual model for conducting nutrient audits at national, regional and global scales. Nutrient Cycling in Agroecosystems, 62, 61-67.

Siebers, N., \& Leinweber, P. (2013). Bone char: A clean and renewable phosphorus fertilizer with cadmium immobilization capability. Journal of Environmental Quality, 42, 405411.

Sirius Minerals. (2016). http://siriusminerals.com/our-project/ mine-and-mineral-transport. Accessed January 18, 2017.

Smil, V. (2001). Enriching the earth. Boston, MA: MIT University Press.
Smith, P., Gregory, P. J., van Vuuren, D., Obersteiner, M., Havlik, P., Rounsevell, M., et al. (2010). Competition for land. Philosophical Transactions of the Royal Society B, London, 365, 2941-2957.

Talboys, P. J., Heppell, J., Roose, T., Healey, J. R., Jones, D. L., \& Withers, P. J. A. (2016). Struvite: A slow-release fertiliser for sustainable phosphorus management? Plant and Soil, 401, 109-123.

Ulrich, A. E., \& Frossard, E. (2014). On the history of a reoccurring concept: Phosphorus scarcity. Science of the Total Environment, 490, 694-707.

USGS. (2011). Mineral commodities summary, appendices. United States Geological Survey (USGS), Reston, Virginia, USA. http://minerals.usgs.gov/minerals/pubs/mcs/2012/mcsapp2012. pdf. Accessed January 18, 2017.

Van Kauwenbergh, S. J. (2010). World phosphate rock reserves and resources. International Fertilizer Development Center. www.ifdc.org. Accessed January 18, 2017.

Vitousek, P. M., Naylor, R., Crews, T., David, M. B., Drinkwater, L. E., Holland, E., et al. (2009). Nutrient imbalances in agricultural development. Science, 324, 1519-1520.

Wang, C., Yue, H., Li, C., Liang, B., Zhu, J., \& Xie, H. (2014). Mineralization of $\mathrm{CO}_{2}$ using natural K-feldspar and industrial solid waste to produce soluble potassium. Industrial and Engineering Chemistry Research, 53, 7971-7978.

White, A. F., \& Brantley, S. L. (2003). The effect of time on the weathering of silicate minerals: Why do weathering rates in the laboratory and field? Chemical Geology, 202, 479-506.

Woods, P. J. E. (1979). The geology of Boulby Mine. Economic Geology, 74, 409-418.

Wien Universität. (2014). Global material flows database. www. materialflows.net. Accessed January 18, 2017.

World Bank World Development Indicators. (2016). http://data. worldbank.org/products/wdi. Accessed January 18, 2017. 